\title{
Analysis of the Ability of School Supervisors in Increasing the Supervision of School Principals of Junior High School at Pidie District
}

\author{
Basri \\ Lecturer in Jabal Ghafur University, Sigli-Aceh, Indonesia \\ basri6609@gmail.com
}

\begin{abstract}
The background of this research is related to the development of the direction of the ability of school supervisors, especially school principals at the junior secondary level, which are influenced by internal factors including: the level of readiness of supervisors, principals, curriculum devices, administration and management, then the readiness of external factors which include: lack of available amenities; the lack of disciplines in accordance with the situation in the field as an effort to support the achievement of better education and teaching. The method used is descriptive meaning to describe the factors that affect the ability of school supervisors competency of the Principal in Pidie District. Data collection techniques used were observation, interview and documentary study techniques, while the research subjects were supervisors, principals, totaling 20 people. The results showed that there were several factors that could influence the performance of school principals including: internal factors affecting the ability of supervisors, principals' competencies, among others, their level of education, experience and years of work, because this affected the level of readiness of school supervisors and principals in carrying out the activity. Then proceed with external factors that are considered to affect the ability of school supervisors, the competency of school principals, namely the availability of facilities and infrastructure as evidence to support the learning process, the achievement of learning directions as desired, improving the performance and supervision of school principals as well as adequate levels of welfare around 85,65\%.
\end{abstract}

Keywords: analization; ability; controlling; the performance

\section{Introduction}

In terms of various aspects, educational institutions achieving predetermined goals are very dependent on the principal to mobilize, motivate and improve the ability of professional teachers so that they can help carry out their duties effectively. The principal has a very strategic role in the learning process in his school in order to improve the quality of education.

On the other hand, supervisors are required to carry out supervisory and coaching duties to regain the support of principals who are currently not excessive must be approved in advance and they must be in the right conditions. The presence of school supervisors who support the work spirit of school principals will have a direct impact on teacher performance. If the improvement of school performance increases, there will be concrete action from them to fix the problem of education that is fixing change in Aceh.

To maintain stability and improve the performance of school principals, school supervisors are required to make concrete and continuous efforts. Efforts to improve the performance of school principals by supervisors are very important and can be implemented in various ways. The creativity of education supervisors is very important in finding appropriate and reliable ways to improve the performance of junior high school principals.

But in the challenge, the performance of school principals is still low and the efforts made by supervisors to improve their performance are also less varied. This is very detrimental to our education system because the government has asked for funds to help solve the problem of school construction. Improving the performance of school principals by supervisors has not 
made a positive contribution to teacher performance. This is what drives the author to conduct research in order to find data on how much effort is needed by junior high school supervisors in improving the performance of the principal under his leadership.

Some of the results of previous studies results of research conducted in the field where in junior high school shows that at this time in a very low place and even the performance reaches the lowest point that is in schools in junior high schools in Pidie District. This is closely related to various problems that befall teachers, school principals, supervisors, and the burning of school buildings during conflicts (unsafe) in large numbers. Maybe this is a condition that has never happened in any country and in the conflict that occurred in Aceh. But what is happening right now is that the most important of higher schools than those in prime schools, Aceh's education is on the verge of extinction difficult to recover.

\section{Review of Literature}

\subsection{Overview of Principal's Performance}

An important role as a leader or better known as the principal is the manager of the education unit responsible for organizing educational activities in his school as a whole through educational management activities as mandated by the 2003 national education system law, in this case generally describing the role, functions and legislation as a school principal whose principal job is generally to carry out school administration with all its substance and increase teachers through supervision activities.

Aside from being the organizer of education, the principal also acts as the manager of the education unit, the principal also acts as the (formal) leader of education at the school level at the elementary, junior high and high school levels. As an educational leader he has a task that must be carried out in managing, carrying out his leadership functions, both functions related to the achievement of objectives and the creation of a conductive school climate for the creation and implementation of teaching and learning processes well.

\subsection{Definition of Supervisor}

Supervisor or better known as supervision in an organization both social, educational, cultural arts and so forth. According to Sergiovanni (1997) the main task/function of supervision / guidance is to "improve the teaching situation. Because coaching is not to try someone but to help, encourage and provide confidence to the coached (headmaster/teacher), that this attitude of leadership, and self-ability can and must always be improved and improved". Soetjipto (2009:56) in his Teaching Profession book are:

The supervisor/supervisor's duties include: curriculum development, teaching organization, fulfillment of facilities, design and acquisition of teaching materials in accordance with curriculum design, teaching and learning experience, implementation of oriantasi about a new task or way in teaching and learning, coordination between teaching and learning activities with service activities, community relations development and teaching implementation.

Educational supervisors are also called education supervisors. In a narrow sense, supervisor means a person who supervises. In the English-Indonesian dictionary, supervisor means supervisor.

In the Decree of the Minister of State for Administrative Reform number 118/1996 and Decree of the Minister of Religion number 381 of 1999 it is stated that the school supervisor / 
supervisor of religious education is a civil servant who is given full duties, responsibilities and authority by the authorized official to conduct supervision on the implementation of education /religious education in public schools and in madrasas by carrying out assessments and guidance in terms of technical education and administration in pre-school, elementary and secondary education units.

Some education experts also provide an understanding of education supervisors, including:

1. Nick Cowell and Roy Gardner, education supervisors are people who help schools and teachers help students learn more, faster, happily and more easily and efficiently.

2. Ary H. Gunawan, education supervisor is the person who carries out supervision work.

3. Piet. A. Sah understanding and Frans Mataheru, education supervisors are people who function to provide assistance to teachers in stimulating teachers towards efforts to maintain a better atmosphere of learning and teaching.

4. Soewadji Lazaruth, education supervisor is everyone who helps or helps the teacher so that the teaching and learning situation develops more effectively.

From the understanding of education supervisors by these experts, the authors conclude that the understanding of education supervisors or education supervisors is those who help schools, teachers and students to learn better.

\subsection{School Supervisors Functions and Duties}

According to the Decree of the Minister of Education and Culture of the Republic of Indonesia Number 020/U/1998 chapter I letter C, "The duty, responsibility and authority of supervisors is to supervise in schools by carrying out assessments and guidance in terms of school technical and administration".

Furthermore, in this decree, the fields and elements of supervisory activities are explained, which include:

a. Education includes:

1. Attend school education and obtain a degree / diploma.

2. Attend education and official trainers and obtain a Certificate of Completion of Education and Training (SLTPL).

b. School Supervision, including:

1. Compile a school supervision program.

2. Assess student learning outcomes / guidance and teacher ability.

3. Collecting and processing data on educational resources, teaching/learning processes and school environment.

4. Analyze learning outcomes / guidance of students, teachers and educational resources.

5. Carry out coaching to teachers and other staff in the school.

6. Compiling reports and evaluating the results of supervision.

7. Carry out other coaching in schools in addition to teaching and learnin /student guidance.

8. Carry out the results of the evaluation of the results of supervision of all schools in the district/municipality.

c. Professional development, including:

1. Carrying out paperwork / scientific work in the field of school education.

2. Developing guidelines for implementing school supervision.

3. Compiling technical guidance for implementing school supervision.

4. Creating art. 
5. Find the right technology.

d. Supporting school supervision includes:

1. Carry out activities supporting school supervision.

2. Carry out community service activities.

\subsection{The Role of School Supervisors}

A supervisor certainly has a good, measurable, planned and systematic role and function. According to an expert Sergiovanni (1993) states that "supervision is a process designed precisely for, helping teachers and supervisors learn more about their daily tasks; can use their knowledge and abilities in order to provide better services to parents of students and schools, and strive to become a school as an effective learning community.

In addition to the functions and duties of the school supervisor also acts as the School Supervision. The main activity of schooling in an effort to achieve its goals is the teaching and learning process. Therefore, in the activities of school organizations that are supported by hardware and software relies on achieving the efficiency and effectiveness of teaching. School efficiency and effectiveness is a component of school policy nationally, it is closely related to other components such as participation, quality, and relevance.

Educational activities in schools need to be maintained and developed in harmony with the growth of the concepts of knowledge and technology. However activities without regard to administrative functions are the result cannot be expected. One of the functions of education administration is supervision.

\subsection{The Ways of Supervisors to Improve School Principal Performance}

How to carry out supervision, a leader is not the same as another leader. This depends on the type of staff of the leadership style. An authoritarian supervises to find out the mistakes of officers in carrying out their duties, namely carrying out the rules and instructions given by the center to his subordinates. The school principal who made a lot of mistakes, got a bad condition, and for him was no longer nominated to occupy a higher rank / position, there was no attempt from him to provide guidance from the leadership

As for supervisors with the pattern of Laissez faire or stupid period do not carry out supervision. She/He lets all school principals and teachers work independently according to their own wishes. She/He left all school activities not supervised at all. School life is chaotic, work programs don't exist; no organization and coordination; the limits of power and responsibility of each are unclear, order is less clear, even non-existent; infrastructure is not maintained and scattered everywhere; the building and yard are neglected and dirty; lethargic atmosphere and poor teaching results. In such school life, confusion and disputes easily arise, because all school principals carry out their duties according to their respective policies and interests, which sometimes conflict with one another.

\section{Research Methods}

This research uses descriptive method, because this study aims at the current conditions, namely; techniques or methods used by school supervisors to improve the performance of Pidie Regency Middle School principals.

Based on this understanding, then the population in this study were all supervisors and principals of Pidie District Junior High School, totaling 33 people. 
Data collection techniques as follows:

1. Observation

2. Interviews, conducted with school principals and supervisors to complete the data collected by questionnaire

3. Documentation

\section{Results and Discussion}

A description of the research data presented firstly on the implementation of the improvement of School Principals of Junior High School at Pidie District by school supervisors. Secondly, the techniques used by school supervisors of Pidie District in improving the performance of junior high school principals in Pidie District. And thirdly, the obstacles experienced by school supervisors in making efforts to improve the performance of junior high school principals in Pidie District.

\subsection{Research Results}

According to school supervisors of Pidie District, the school principal's performance improvement activities were of particular concern. This statement is supported by the attention of supervisors on the implementation of the principals' tasks in planning, implementing and supervising the activities of principals. Therefore the principal needs help to obtain these three elements.

This important information is expressed based on an assumption that the education supervisor's perception of his role as a coach has an influence on how the attention and intensity of the supervisor's activities to improve the performance of the principal.

The results showed that education supervisors know and understand their role as coaches and also know that improving the performance of school principals is an important issue and must be implemented properly, this is based on the reasons they give that their task is how to improve the performance of school principals as well -baiklah so that the quality of education will improve, therefore as a school supervisor gives direction, guidance, examples and suggestions needed to improve the performance of the principal. Focus on improving the performance of the principal by visiting the school to provide direction, guidance, examples and advice in improving the performance of the principal in order to achieve the educational and teaching objectives as optimal as possible.

Field research results explain that there are several factors that can affect the performance of principals including: internal factors that affect the ability of supervisors, principals' competencies, among others, level of education, experience and years of work, because this is what influences the level of readiness of school supervisors and principals in carry out activities. Then proceed with external factors that are considered to affect the ability of school supervisors, the competency of school principals, namely the availability of facilities and infrastructure as evidence to support the learning process, the achievement of learning directions as desired, improving the performance and supervision of school principals as well as adequate levels of welfare around $85.65 \%$.

\section{A. Work Program of School Supervisor of Pidie District}

The results of interviews and research by the author, the supervisor had a detailed program of activities every semester to be carried out in one academic year. The work program as written in the work guidelines for the school supervisors of Pidie District Education Office is as follows: 
1) Odd semester program

- Monitoring and guiding the implementation of new student admissions.

- Collecting and managing data on PBM/guidance and educational resources and school environment that influence the development and learning outcomes of student guidance.

- Analyzing learning outcomes/student guidance, teachers and educational resources that affect student learning outcomes/guidance to determine the type of coaching (simple comprehensive analysis).

- Guiding principal's administrative (school annual program, principal's work program, principal's work program, TU work program).

- Providing direction and guidance to teachers about PBM implementation/student guidance.

\section{B. Activities of School Supervisor of Pidie District in Improving School Principal Performance}

The activity of Education Supervisor of Banda Aceh City in improving the performance of Principal are coaching, self-development, quality and management improvement and protection.

1) Coaching

Based on the results of interviews and researchers' documentation studies, supervisors provide guidance, guidance, examples and suggestions to the principal at every opportunity that exists, such as in every visit to the school, in meetings with other school principals (meetings at KKKS or at MKKS) and in other possible opportunities.

2) Self-development

In terms of the Principal's self-development, supervisors provide ample opportunity to develop, for those who want to continue their education it will be easy to get permission, as well as to attend upgrading or increasing the school principal's insight. Whereas in the development of increased insight through reading books or educational magazines / journals, it cannot be carried out maximally because the available materials are not yet abundant. While the supervisors themselves have not been able to provide a special library that concerns the head of the school.

3) Quality improvement and management

In terms of improving the quality of school principals, according to the observations of researchers not much different from those in terms of self-development such as attending various seminars, meeting with fellow principals and others. Principals' rotation and rotation within a certain time frame, according to supervisors, is also one way to improve their quality in addition to improving the quality of the schools they lead. It is not uncommon for school principals to feel that they have their own challenges if they are placed in schools whose quality is not good.

\section{Discussion}

The development of the Principal's professional abilities is important and needs to get the attention of school supervisors in particular and related institutions in general in order to improve the quality of the Principal which will have an impact on improving the quality of teachers and ultimately improving the quality of education desired, because professional principals are expected will be able to carry out the task well, able to solve the problems faced, have independence, have high creativity, great motivation and have adequate innovation 
capabilities, which will ultimately improve the quality of education expected. Efforts that must be carried out by supervisors and related institutions in enhancing the Principal's professional abilities such as by increasing creativity, including modern educational seminars and workshops, supplementing modern public reading and knowledge including accessing from the internet are things that should be realized immediately. The results showed that there were several factors that could influence the performance of school principals including: internal factors affecting the ability of supervisors, principals' competencies, among others, their level of education, experience and years of work, because this affected the level of readiness of school supervisors and principals in carrying out the activity. Then proceed with external factors that are considered to affect the ability of school supervisors, the competency of school principals, namely the availability of facilities and infrastructure as evidence to support the learning process, the achievement of learning directions as desired, improving the performance and supervision of school principals as well as adequate levels of welfare around $85.65 \%$.

\section{Conclusions}

Guidance and supervision conducted by supervisors are; supervisors come to school between two to four times a year by giving direction in accordance with the current coaching theme such as directing the problem of admission of new students at the beginning of the year, information and guidance on conducting general tests at the end of the semester and School Final Exam / National Exam towards the end of the year. Coaching visits tailored to the needs of special guidance the supervisor will come more often, and vice versa if the school is considered sufficient, then the visit is carried out in moderation.

Supervisors' efforts to improve the performance of school principals to be more professional are to assess how much progress they have achieved, including assessments of teachers under the guidance of the school principal concerned. To deepen the Principal's insight, a discussion is held through the KKKS forum at least twice a month. Discussion of material can be in the form of the results of the experience of the Principal who has just attended the upgrading or experience in the field. The supervisor will also give permission for school principals who wish to continue their education to a higher level, even though until now there is no scholarship. Regarding the existence of KKKS and PGRI, to date the two institutions are still needed but should adopt a new paradigm that is more professional and rooted.

\section{References}

Atmodiwirio, S \& Toto Sismanto, S. (1981). Kepempimpinan Kepala Sekolah, CV. Adhiwaskita. Semarang.

Departemen Pendidikan dan Kebudayaan, Keputusan Bersama Materi Kepengawai dan Kebudayaan dan Kepala Badan Adminidtrasi 1996 tentang Petunjuk Pelaksanaan Jabatan Fungsional Pengawas Sekolah dan Angka Kreditnya, (1999). Jakarta. Debdikbud Republik Indonesia.

Soetjipto. (2009). Tugas Pokok, Kedudukan Pengawas dan Kepala Sekolah SMP-SMA dalam Satu Instansi Sekolah. PT. Remaja Rosdakarya. Bandung.

Sergiovanni. (1997). Tugas Pokok, Kedudukan Pengawas dan Kepala Sekolah dalam Satu Instansi Sekolah. CV. Deepublish. Yogyakarta. 